\title{
New sympathicotomy for prevention of severe compensatory hyperhidrosis in patients with primary hyperhidrosis
}

\author{
Jung Wook Han, Jae Jun Kim, Yong Hwan Kim, In Sub Kim, Seong Cheol Jeong \\ Department of Thoracic and Cardiovascular Surgery, Uijeongbu St. Mary's Hospital, College of Medicine, The Catholic University of Korea, \\ Geumo-dong, Uijeongbu, Gyeonggi-do, Republic of Korea \\ Contributions: (I) Conception and design: JW Han, JJ Kim; (II) Administrative support: JJ Kim; (III) Provision of study materials or patients: YH Kim; \\ (IV) Collection and assembly of data: IS Kim, SC Jeong; (V) Data analysis and interpretation: JJ Kim, JW Han; (VI) Manuscript writing: All authors; \\ (VII) Final approval of manuscript: All authors. \\ Correspondence to: Jae Jun Kim, MD, PhD. Department of Thoracic and Cardiovascular Surgery, Uijeongbu St. Mary's Hospital, College of Medicine, \\ The Catholic University of Korea, Geumo-dong, Uijeongbu, Gyeonggi-do, 480-717, Republic of Korea. Email: medkjj@hanmail.net.
}

Background: Primary hyperhidrosis $(\mathrm{PH})$ is characterized by excessive and uncontrollable secretion in the eccrine sweat glands of the craniofacial region, armpits, hands, and feet. Sympathicotomy is the most effective treatment for severe $\mathrm{PH}$; however, compensatory hyperhidrosis $(\mathrm{CH})$ remains the most devastating postoperative complication. The purpose of the present study was to suggest a new sympathicotomy method for $\mathrm{PH}$ to prevent severe $\mathrm{CH}$.

Methods: From March 2014 to December 2018, a total of 212 patients were included in the study. R2 (53 cases) sympathicotomy for craniofacial hyperhidrosis and R3 (79 cases) or R4 (80 cases) sympathicotomy for palmar hyperhidrosis using the thoracoscopic technique were performed, respectively. Sympathicotomy was performed using two different methods (conventional 145 cases and new 67 cases). Expanded sympathicotomy was performed as the new method (67 cases), which was divided into two groups (partialand full-expanded sympathicotomy). Operative effectiveness was evaluated by a reduction in percentage of post-operative sweating compared with pre-operative sweating and groups were divided into complete and incomplete sweat reduction characteristics. Complete sweat reduction was defined as sweat reduction $\geq 80 \%$ compared with preoperative sweating. The degrees of $\mathrm{CH}$ were classified as negligible, mild bothering (tolerable), and severe bothering (intolerable). Data on preoperative subject characteristics, disease status, operative technique, and postoperative outcomes were gathered using medical records and telephone surveys. Results: According to sympathicotomy techniques, the conventional procedure (non-expanded sympathicotomy) was performed in 145 cases and the new expanded sympathicotomy procedure was performed in 67 cases (partial-expanded sympathicotomy 28 cases; full-expanded sympathicotomy 39 cases). Craniofacial hyperhidrosis was significantly more prevalent in the older group and in female patients $(\mathrm{P}<0.001$ and $\mathrm{P}=0.007$, respectively). Sympathicotomy was significantly more effective in palmar hyperhidrosis than craniofacial hyperhidrosis $(\mathrm{P}<0.001)$. $\mathrm{CH}$ was significantly more severe in craniofacial hyperhidrosis than palmar hyperhidrosis after sympathicotomy $(\mathrm{P}<0.001)$. In craniofacial hyperhidrosis, there was no significant difference in sweat reduction and $\mathrm{CH}$ between conventional and the expanded sympathicotomy techniques $(\mathrm{P}=0.177$ and $\mathrm{P}=0.474$, respectively). In palmar hyperhidrosis, there was no significant difference in sweat reduction between the conventional and the expanded sympathicotomy $(\mathrm{P}=0.178)$, however, degree of $\mathrm{CH}$ in the conventional technique was significantly more severe than in the expanded technique $(\mathrm{P}=0.001)$. Regarding comparison between partial- and full-expanded sympathicotomy, there was no significant difference in sweat reduction between partial-, and full-expanded sympathicotomy; however, $\mathrm{CH}$ was significantly more severe in partial-expanded sympathicotomy (craniofacial hyperhidrosis $\mathrm{P}=0.006$; palmar hyperhidrosis $\mathrm{P}<0.001)$. Irrespective of hyperhidrosis types, there was no significant difference in sweat reduction between full-expanded and the others (non-expanded and partial-expanded sympathicotomy), however, full-expanded sympathicotomy showed a significantly less degree of $\mathrm{CH}$ than non-expanded and partial-expanded sympathicotomy (craniofacial, $\mathrm{P}=0.002$; palmar, $\mathrm{P}<0.001$ ). 


\begin{abstract}
Conclusions: Full-expanded sympathicotomy is a safe and feasible treatment that shows a significant decrease in the degree of $\mathrm{CH}$ with the same effect in sweat reduction in both craniofacial and palmar hyperhidrosis. Importantly, no severe $\mathrm{CH}$ developed after a full-expanded sympathicotomy without any major postoperative complications.
\end{abstract}

Keywords: Sympathicotomy; compensatory hyperhidrosis $(\mathrm{CH})$; primary hyperhidrosis $(\mathrm{PH})$

Submitted Sep 14, 2019. Accepted for publication Dec 10, 2019.

doi: $10.21037 /$ jtd.2019.12.91

View this article at: http://dx.doi.org/10.21037/jtd.2019.12.91

\section{Introduction}

Primary hyperhidrosis $(\mathrm{PH})$ is characterized by excessive and uncontrollable secretion in the eccrine sweat glands of the craniofacial region, armpits, hands, and feet $(1,2)$. $\mathrm{PH}$ is generally considered to be associated with sympathetic nervous dysfunction; however, its etiology remains unclear (1-3). PH leads despairing impacts on quality of life $(1,2)$. The treatment modality for $\mathrm{PH}$ includes a range of topical or systemic medications, psychotherapy, and surgical or non-surgical approaches (3-5). Many studies have been conducted to manage $\mathrm{PH}$ and sympathicotomy is the most effective for $\mathrm{PH}$ when conservative treatment has failed (6-9). However, in spite of advances in surgical techniques for sympathicotomy, compensatory hyperhidrosis $(\mathrm{CH})$ remains the most important postoperative complication, which occasionally causes patients to regret receiving sympathicotomy and surgeons to hesitate to use a prompt sympathicotomy as the first treatment modality for $\mathrm{PH}$, especially for craniofacial hyperhidrosis $(4,10-12)$. The pathogenesis of $\mathrm{CH}$ is hypothesized to be caused by a dysfunctional reflex arc from the sympathetic nervous system to hypothalamus, which causes uncontrollable and excessive sweat in other parts of the body $(13,14)$. Many studies have been performed, and some risk factors for $\mathrm{CH}$ and the extent of sympathicotomy have been suggested $(6,7,11,15-18)$. However, many questions remain. The purpose of the present study was to suggest a new sympathicotomy method for $\mathrm{PH}$ to prevent severe $\mathrm{CH}$.

\section{Methods}

From March 2014 to December 2018, patients with PH who had undergone sympathicotomy and met the inclusion criteria were included in the study. Inclusion criteria for the study were as follows: (I) localized PH mainly in the craniofacial region and hands; (II) no previous thoracic surgery including sympathicotomy for PH; (III) no medication intake; and (IV) no definitive psychological problems $(11,15)$. Our new technique was initiated in January 2017. All patients received sympathicotomy using the thoracoscopic technique on hospitalization. Data on preoperative subject characteristics, disease status, operative technique, and postoperative outcomes were gathered using medical records and telephone surveys. The telephone survey questionnaire consisted of determining changes in preoperative $\mathrm{PH}$, degree and localization of $\mathrm{CH}$, and recurrence or failure. Operative effectiveness was evaluated by a reduction in percentage of post-operative sweating compared with pre-operative sweating and groups were divided into complete and incomplete sweat reduction characteristics. Complete sweat reduction was defined as sweat reduction $\geq 80 \%$ compared with preoperative sweating. Incomplete sweat reduction included cases with sweat reduction $<80 \%$ and recurrence. The degrees of $\mathrm{CH}$ were classified as negligible, mild bothering (tolerable), and severe bothering (intolerable). Gustatory hyperhidrosis was not evaluated and was excluded. All subjects were routinely assessed one month after sympathicotomy.

\section{Sympathicotomy methods}

R2 sympathicotomy for craniofacial hyperhidrosis and R3 or R4 sympathicotomy for palmar hyperhidrosis using the thoracoscopic technique were performed, respectively (7). Sympathicotomy was performed using two different methods (conventional and new). In the previous conventional method (non-expanded sympathicotomy), patients were put under general anesthesia with double lumen endotracheal anesthesia in the supine position. Patients underwent a $5-\mathrm{mm}$, two-port thoracoscopic sympathicotomy with a $\mathrm{CO}_{2}$ gas insufflation $(10-20 \mathrm{mmHg})$ via the fifth intercostal space on the anterior axillary line and 
Table 1 The overall clinical characteristics of the study subjects

\begin{tabular}{|c|c|c|c|}
\hline \multirow[b]{2}{*}{ Variables } & \multicolumn{2}{|c|}{ Hyperhidrosis } & \multirow[b]{2}{*}{$P$ value } \\
\hline & $\begin{array}{l}\text { Craniofacial } \\
\text { type }\end{array}$ & $\begin{array}{l}\text { Palmar } \\
\text { type }\end{array}$ & \\
\hline Age (year) & $47.6 \pm 9.2$ & $23.7 \pm 11.1$ & $<0.001$ \\
\hline Age group & & & $<0.001$ \\
\hline $\begin{array}{l}\text { Young group ( } \leq 30 \text { years } \\
\text { old) }\end{array}$ & 6 & 124 & \\
\hline Old group (>30 years old) & 47 & 35 & \\
\hline Sex & & & 0.007 \\
\hline Male & 24 & 105 & \\
\hline Female & 29 & 54 & \\
\hline Level of sympathicotomy & & & $<0.001$ \\
\hline $\mathrm{R} 2$ & 53 & 0 & \\
\hline R3 & 0 & 79 & \\
\hline $\mathrm{R} 4$ & 0 & 80 & \\
\hline Sympathicotomy technique & & & 0.670 \\
\hline Non-expanded & 35 & 110 & \\
\hline Expanded & 18 & 49 & \\
\hline Sweat reduction & & & $<0.001$ \\
\hline Complete & 40 & 153 & \\
\hline Incomplete & 13 & 6 & \\
\hline $\begin{array}{l}\text { Compensatory } \\
\text { hyperhidrosis }\end{array}$ & & & $<0.001$ \\
\hline Negligible & 8 & 66 & \\
\hline Tolerable & 29 & 85 & \\
\hline Intolerable & 16 & 8 & \\
\hline
\end{tabular}

the sixth intercostal space on the mid-axillary line. To recover from severe $\mathrm{CH}$, the sympathetic chains were clipped with a 5-mm metal clip instead of transection (16,19-21). Due to possible accessary bypass nerve routes, we electro-cauterized laterally along the rib surfaces by a few centimeters. In the new method (expanded sympathicotomy), patients were put under general anesthesia with single lumen endotracheal anesthesia in the prone position, underwent a $5-\mathrm{mm}$, twoport thoracoscopic sympathicotomy using a $\mathrm{CO}_{2}$ gas insufflation via the sixth intercostal space on the mid-axillary line and the seventh intercostal space on the post-axillary line. In addition to the conventional sympathicotomy, we expanded the level of sympathicotomy to levels ranging from $\mathrm{R} 5$ to $\mathrm{R} 12$ by chain ablation to prevent $\mathrm{CH}$ while avoiding injury to the splanchnic nerves. The expanded sympathicotomy cases were divided into two groups (partialand full-expanded sympathicotomy). A partial-expanded sympathicotomy was defined as cases with sympathicotomy expanded to R8 and full-expanded sympathicotomy was defined as cases with sympathicotomy expanded beyond $\mathrm{R} 8$ to levels ranging from $\mathrm{R} 9$ to $\mathrm{R} 12$. When expanded sympathicotomy was performed in cases of craniofacial hyperhidrosis, we did not perform sympathicotomy at the level of R3 and R4 to prevent possible unnecessary effects on the hands, such as dry hands. A 16-Fr chest tube was placed in the pleural cavity when ports were removed, and the chest tube was removed once the air ceased to flow out after full lung expansion. Patients were usually discharged the day following operation.

\section{Statistical considerations and ethical statement}

All data are presented as the mean \pm SD. Student's $t$-tests were used for continuous independent variables. The chisquare statistic was used to check relationships between categorical variables. The results were analyzed using the Statistical Package of Social Sciences version 22.0 (SPSS, IBM Corp, NY, USA), with a value of significance at 0.05 . Approval from Uijeongbu Saint Mary's Hospital Ethics Committee was obtained for the present study (Approval number: UC19RESI0119).

\section{Results}

A total of 212 patients were included in the study. The mean age of study subjects was $29.6 \pm 14$.9 years at the age of surgery and the mean observation periods was $26.7 \pm 18.2$ months. Of the included patients, 129 were male and 83 were female. The hyperhidrosis types included 53 craniofacial and 159 palmar cases. According to sympathicotomy techniques, the conventional procedure was performed in 145 cases and the new expanded sympathicotomy procedure was performed in 67 cases. Sympathicotomy levels were performed as follows: 53 at R2, 79 at R3 and 80 at the R4 levels. There were no postoperative mortalities or major complications. All patients receiving expanded sympathicotomy showed no $\mathrm{CH}$ in the upper body, but some in the lower body (under level of umbilicus). The overall clinical characteristics of the study subjects are presented in Table 1 . 
Table 2 Comparison between R3 and R4 sympathicotomy for palmar hyperhidrosis

\begin{tabular}{lccc}
\hline \multirow{2}{*}{ Palmar hyperhidrosis } & \multicolumn{2}{c}{ Sympathicotomy } & \multirow{2}{*}{ P value } \\
\cline { 2 - 3 } & $\mathrm{R} 3$ & $\mathrm{R} 4$ & \\
\hline Sweat reduction & 79 & 74 & 0.028 \\
Complete & 0 & 6 & \\
Incomplete & & & 0.253 \\
Compensatory hyperhidrosis & 36 & 30 & \\
Negligible & 41 & 44 & \\
Tolerable & 2 & 6 & \\
Intolerable & & & \\
\hline
\end{tabular}

\section{Hyperbidrosis according to age and sex}

All subjects were divided into two groups according to age [young group (YG) $\leq 30$ years $v s$. old group (OG) $>30$ years old]. The YG included 130 cases and the OG included 82 cases. Craniofacial hyperhidrosis was significantly more prevalent in the $O G$ and in female patients $(\mathrm{P}<0.001$ and $\mathrm{P}=0.007$, respectively) (Table 1$)$.

\section{Overall sweat reduction after sympathicotomy according to hyperhidrosis type and sympatbicotomy}

R2 sympathicotomy was performed in all craniofacial hyperhidrosis cases and R3 or R4 sympathicotomy was performed in palmar hyperhidrosis cases. Symptoms in all patients improved immediately after sympathicotomy. According to the definition for effectiveness of sweat reduction in the present study, complete sweat reduction was achieved in 40 of 53 patients with craniofacial hyperhidrosis and in 153 of 159 patients with palmar hyperhidrosis. Sympathicotomy for palmar hyperhidrosis was significantly more effective in sweat reduction $(\mathrm{P}<0.001)$ (Table 1). In, addition, R3 sympathicotomy in 79 cases and R4 sympathicotomy in 80 cases were performed for palmar hyperhidrosis. R3 sympathicotomy was significantly more effective in sweat reduction than $\mathrm{R} 4$ sympathicotomy $(\mathrm{P}=0.028)$ (Table 2).

\section{Overall CH after sympathicotomy according to byperhidrosis type and sympatbicotomy}

We divided the degree of $\mathrm{CH}$ into negligible, mild bothering, and severe bothering. In craniofacial hyperhidrosis, negligible, mild bothering, and severe bothering $\mathrm{CH}$ included 8,29 , and 16 cases, respectively. In palmar hyperhidrosis, negligible, mild bothering, and severe bothering $\mathrm{CH}$ included 66,85 , and 8 cases, respectively. $\mathrm{CH}$ was significantly more severe in craniofacial hyperhidrosis after sympathicotomy $(\mathrm{P}<0.001)$ (Table 1). In addition, in R3 sympathicotomy for palmar hyperhidrosis, negligible, mild bothering, and severe bothering $\mathrm{CH}$ included 36, 41, and 2 cases, respectively. In R4 sympathicotomy for palmar hyperhidrosis, negligible, mild bothering, and severe bothering $\mathrm{CH}$ were found 30 , 44, and 6 cases, respectively. There was no statistically significant difference between R3 and R4 sympathicotomy for palmar hyperhidrosis $(\mathrm{P}=0.253)$ (Table 2).

\section{Comparison according to sympathicotomy methods (non- expanded vs. expanded sympatbicotomy)}

Expanded sympathicotomy was performed in 18 of 53 patients with craniofacial hyperhidrosis and in 49 of 159 patients with palmar hyperhidrosis. In craniofacial hyperhidrosis, there was no significant difference in sweat reduction and $\mathrm{CH}$ between conventional and the expanded sympathicotomy techniques $(\mathrm{P}=0.177$ and $\mathrm{P}=0.474$, respectively). In palmar hyperhidrosis, there was no significant difference in sweat reduction between the nonexpanded and the expanded sympathicotomy $(\mathrm{P}=0.178)$, however, the degree of $\mathrm{CH}$ was significantly more severe in non-expanded sympathicotomy $(\mathrm{P}=0.001)$ (Table 3).

\section{Comparison between the partial-and full-expanded sympatbicotomy}

The expanded sympathicotomy cases were divided in two groups (partial- and full-expanded sympathicotomy). Partial-expanded sympathicotomy were performed in 28 cases and full-expanded sympathicotomy was performed in 39 cases. In craniofacial hyperhidrosis, there was no significant difference in sweat reduction between partialand full-expanded sympathicotomy $(\mathrm{P}=0.529)$; however, $\mathrm{CH}$ was significantly more severe in partial-expanded sympathicotomy $(\mathrm{P}=0.006)$. In palmar hyperhidrosis, there was no significant difference in sweat reduction between partial-, and full-expanded sympathicotomy; however, $\mathrm{CH}$ was significantly more severe in partial-expanded sympathicotomy $(\mathrm{P}<0.001)$ (Table 4). 
Table 3 Comparison of between non-expanded and expanded sympathicotomy

\begin{tabular}{|c|c|c|c|}
\hline \multirow{2}{*}{ Variable } & \multicolumn{2}{|c|}{ Sympathicotomy } & \multirow{2}{*}{$P$ value } \\
\hline & Non-expanded & Expanded & \\
\hline \multicolumn{4}{|c|}{ Craniofacial hyperhidrosis } \\
\hline Sweat reduction & & & 0.177 \\
\hline Complete & 24 & 16 & \\
\hline Incomplete & 11 & 2 & \\
\hline $\begin{array}{l}\text { Compensatory } \\
\text { hyperhidrosis }\end{array}$ & & & 0.474 \\
\hline Negligible & 4 & 4 & \\
\hline Tolerable & 19 & 10 & \\
\hline Intolerable & 12 & 4 & \\
\hline \multicolumn{4}{|c|}{ Palmar hyperhidrosis } \\
\hline Sweat reduction & & & 0.178 \\
\hline Complete & 104 & 49 & \\
\hline Incomplete & 6 & 0 & \\
\hline $\begin{array}{l}\text { Compensatory } \\
\text { hyperhidrosis }\end{array}$ & & & 0.001 \\
\hline Negligible & 36 & 30 & \\
\hline Tolerable & 66 & 19 & \\
\hline Intolerable & 8 & 0 & \\
\hline
\end{tabular}

Comparison between the partial-expanded sympathicotomy and non-expanded sympathicotomy

Non-expanded and partial- expanded sympathicotomy was performed in 145 and 28 cases, respectively. There was no significant difference in sweat reduction and degree of $\mathrm{CH}$ between partial-expanded sympathicotomy and non-expanded sympathicotomy, irrespective of hyperhidrosis types (Table 5).

\section{Comparison according to the extent of sympathicotomy when partial-expanded was included into the non-expanded group}

Because partial and non-expanded hyperhidrosis did not show a difference in surgical outcomes and partial- and fullexpanded sympathicotomy were different in $\mathrm{CH}$, we included partial-expanded sympathicotomy into non-expanded cases. Irrespective of hyperhidrosis types, there was no significant difference in sweat reduction, however, full-expanded sympathicotomy showed a significantly less degree of $\mathrm{CH}$ (craniofacial, $\mathrm{P}=0.002$; palmar, $\mathrm{P}<0.001$ ) (Table 6).
Table 4 Comparison between partial- and full-expanded sympathicotomy

\begin{tabular}{|c|c|c|c|}
\hline \multirow{2}{*}{ Variable } & \multicolumn{2}{|c|}{ Expanded sympathicotomy } & \multirow{2}{*}{ - P value } \\
\hline & Partial & Full & \\
\hline \multicolumn{4}{|c|}{ Craniofacial hyperhidrosis } \\
\hline Sweat reduction & & & 0.529 \\
\hline Complete & 10 & 6 & \\
\hline Incomplete & 2 & 0 & \\
\hline $\begin{array}{l}\text { Compensatory } \\
\text { hyperhidrosis }\end{array}$ & & & 0.006 \\
\hline Negligible & 0 & 4 & \\
\hline Tolerable & 8 & 2 & \\
\hline Intolerable & 4 & 0 & \\
\hline \multicolumn{4}{|c|}{ Palmar hyperhidrosis } \\
\hline Sweat reduction & & & NA \\
\hline Complete & 16 & 33 & \\
\hline Incomplete & 0 & 0 & \\
\hline $\begin{array}{l}\text { Compensatory } \\
\text { hyperhidrosis }\end{array}$ & & & $<0.001$ \\
\hline Negligible & 4 & 26 & \\
\hline Tolerable & 12 & 7 & \\
\hline Intolerable & 0 & 0 & \\
\hline
\end{tabular}

\section{Discussion}

Prevalence of $\mathrm{PH}$ ranges from $1-3 \%$ in the general population and $\mathrm{PH}$ shows an equal prevalence in men and women $(1,22)$. Sympathicotomy is the most effective treatment for severe PH $(3,9)$; however, in spite of outstanding sweat reduction after sympathicotomy, $\mathrm{CH}$ occurs with an incidence of about $3 \%$ to $98 \%$ remains the most devastating postoperative complication $(2,14,23)$. CH is the main reason which, on occasion, causes patients to regret receiving sympathicotomy and surgeons to hesitate to use sympathicotomy as the first treatment modality for severe $\mathrm{PH}$, especially in craniofacial hyperhidrosis $(3,10,12)$. Sympathicotomy can be the best choice of treatment for severe $\mathrm{PH}$ if severe $\mathrm{CH}$ can be prevented (16). In addition, because $\mathrm{CH}$ is the most important factor affecting patient satisfaction after sympathicotomy and severe $\mathrm{CH}$ is difficult to treat, prevention of $\mathrm{CH}$ is of the upmost importance $(14,16,17)$. Therefore, we designed a new sympathicotomy method to prevent severe $\mathrm{CH}$ in terms of the extent of 
Table 5 Comparison between non-expanded and partial-expanded sympathicotomy

\begin{tabular}{|c|c|c|c|}
\hline \multirow[b]{2}{*}{ Variable } & \multicolumn{2}{|c|}{ Sympathicotomy } & \multirow[b]{2}{*}{$P$ value } \\
\hline & $\begin{array}{c}\text { Non- } \\
\text { expanded }\end{array}$ & $\begin{array}{l}\text { Partial- } \\
\text { expanded }\end{array}$ & \\
\hline \multicolumn{4}{|l|}{ Craniofacial hyperhidrosis } \\
\hline Sweat reduction & & & 0.464 \\
\hline Complete & 24 & 10 & \\
\hline Incomplete & 11 & 2 & \\
\hline $\begin{array}{l}\text { Compensatory } \\
\text { hyperhidrosis }\end{array}$ & & & 0.620 \\
\hline Negligible & 4 & 0 & \\
\hline Tolerable & 19 & 8 & \\
\hline Intolerable & 12 & 4 & \\
\hline \multicolumn{4}{|l|}{ Palmar hyperhidrosis } \\
\hline Sweat reduction & & & 0.338 \\
\hline Complete & 104 & 16 & \\
\hline Incomplete & 6 & 0 & \\
\hline Compensatory hyperhidrosis & & & 0.380 \\
\hline Negligible & 36 & 4 & \\
\hline Tolerable & 66 & 12 & \\
\hline Intolerable & 8 & 0 & \\
\hline
\end{tabular}

sympathicotomy.

In the present study, 212 patients received thoracoscopic sympathicotomy. All patients' symptoms improved immediately after sympathicotomy. Complete sweat reduction was defined as sweat reduction $\geq 80 \%$ compared with preoperative sweating. Overall operative outcomes in our study showed that complete reduction of sweating was at $75.5 \%$ in craniofacial and $96.2 \%$ in palmar cases and that symptomatic $\mathrm{CH}$ was at $84.9 \%$ in craniofacial and $58.5 \%$ in palmar cases. Similar to other studies, these outcomes were considered very effective for sweat reduction, but problematic for $\mathrm{CH}(4,22)$. To prevent severe $\mathrm{CH}$, the extent of sympathicotomy is the most important issue; however, there is no consensus on the association between $\mathrm{CH}$, the extent of sympathicotomy, and the sympathicotomy technique used (18) as outcomes vary from study to study $(13,16,24-27)$. Some research suggests that $\mathrm{CH}$ is associated with extensive sympathicotomy, while others report that the extent of sympathicotomy has no association with the degree of $\mathrm{CH}(13,16,24-27)$. We assumed that $\mathrm{CH}$ occurs though
Table 6 Comparison between full-expanded sympathicotomy and others (non-expanded and partial sympathicotomy)

\begin{tabular}{|c|c|c|c|}
\hline \multirow{2}{*}{ Variable } & \multicolumn{2}{|c|}{ Expanded sympathicotomy } & \multirow{2}{*}{$P$ value } \\
\hline & Full & others & \\
\hline \multicolumn{4}{|c|}{ Craniofacial hyperhidrosis } \\
\hline Sweat reduction & & & 0.138 \\
\hline Complete & 6 & 34 & \\
\hline Incomplete & 0 & 13 & \\
\hline $\begin{array}{l}\text { Compensatory } \\
\text { hyperhidrosis }\end{array}$ & & & 0.002 \\
\hline Negligible & 4 & 4 & \\
\hline Tolerable & 2 & 27 & \\
\hline Intolerable & 0 & 16 & \\
\hline \multicolumn{4}{|c|}{ Palmar hyperhidrosis } \\
\hline Sweat reduction & & & 0.346 \\
\hline Complete & 33 & 120 & \\
\hline Incomplete & 0 & 6 & \\
\hline \multicolumn{2}{|c|}{ Compensatory hyperhidrosis } & & $<0.001$ \\
\hline Negligible & 26 & 40 & \\
\hline Tolerable & 7 & 78 & \\
\hline Intolerable & 0 & 8 & \\
\hline
\end{tabular}

the remaining sympathetic chains from the hypothalamic reflex arc. This assumption was reasonably demonstrated in some studies, which showed that $\mathrm{CH}$ was limited in the lower body when sympathicotomy was expanded to R7 and thoracic sympathicotomy improved $\mathrm{CH}$ in the trunk when CH developed after sympathicotomy $(10,28,29)$. Therefore, we designed an expanded sympathicotomy technique to reduce $\mathrm{CH}$. Of course, the safety of this procedure should be guaranteed. In regard to safety of the expanded sympathicotomy, the sympathetic chain can be injured in the lower thorax when a severe adhesion is dissected in thoracic surgery or when an extrapleural procedure or pleurectomy is performed; however, no major complications have not been reported due to injury of the sympathetic chains in the lower thorax, except for the splanchnic nerve (30). In addition, the level of sympathicotomy ranged from R1 to R8 in a few studies $(10,28,29)$. Because of these, we assumed that the sympathetic chain in the lower thorax could be cauterized without any major complications. Initially, we expanded the extent of sympathicotomy to R8, and the results did not 
show a difference in $\mathrm{CH}$ and no complications associated with the expanded sympathicotomy developed. Therefore, we expanded sympathicotomy as low as possible beyond $\mathrm{R} 8$, even to R12. The results showed a significantly reduced degree of $\mathrm{CH}$ and, interestingly and importantly, there were no severe $\mathrm{CH}$ cases without major complications. These findings suggest that sympathicotomy can be the best choice of treatment modality for severe $\mathrm{PH}$ and we need not hesitate to perform a prompt sympathicotomy as the first treatment modality for severe $\mathrm{PH}$, even craniofacial hyperhidrosis.

The present study also showed that craniofacial hyperhidrosis was significantly more prevalent in the OG and in female patients. These findings show that hyperhidrosis is associated with various factors as well as the function or balance of the autonomic nerve system $(1,6,10,31)$. In addition, we know that $\mathrm{R} 3$ sympathicotomy is more effective in sweat reduction and more severe in $\mathrm{CH}$ than $\mathrm{R} 4$ sympathicotomy for management of palmar hyperhidrosis $(23,26,28,32)$. Therefore, the level of sympathicotomy cannot yet be defined $(23,26,28,32)$; however, R3 sympathicotomy will be the best level for sympathicotomy when a full-expanded sympathicotomy is performed for palmar hyperhidrosis. Therefore, this study demonstrates that a full-expanded sympathicotomy for $\mathrm{PH}$ can feasibly and safely prevent against severe $\mathrm{CH}$.

The primary limitations of our study included the singlecenter nature of the study, its retrospective nature, and the small sample size for dealing with various factors. Patients in this study were not randomized to type of hyperhidrosis and sympathicotomy. However, because the overall outcomes for sweat reduction and $\mathrm{CH}$ were similar to those previously reported in the literature, the subjects were not considered to create a severe bias $(6,22,32)$. Compared with other studies, we strictly defined the degree of sweat reduction and $\mathrm{CH}$ to more clearly evaluate the effects of the types of sympathicotomy.

\section{Conclusions}

Full-expanded sympathicotomy is a safe and feasible treatment that shows a significant decrease in the degree of $\mathrm{CH}$ with the same effect in sweat reduction in both craniofacial and palmar hyperhidrosis. Importantly, no severe $\mathrm{CH}$ developed after a full-expanded sympathicotomy without any major postoperative complications. Therefore, we recommend a full-expanded sympathicotomy rather than limiting the sympathicotomy level to overcome severe $\mathrm{CH}$. In addition, further studies on full-expanded sympathicotomy are required to prevent severe $\mathrm{CH}$ after sympathicotomy.

\section{Acknowledgments}

Funding: None.

\section{Footnote}

Conflicts of Interest: The authors have no conflicts of interest to declare.

Ethical Statement: The authors are accountable for all aspects of the work in ensuring that questions related to the accuracy or integrity of any part of the work are appropriately investigated and resolved. The study was approved by Uijeongbu Saint Mary's Hospital Ethics Committee (Approval number: UC19RESI0119).

Open Access Statement: This is an Open Access article distributed in accordance with the Creative Commons Attribution-NonCommercial-NoDerivs 4.0 International License (CC BY-NC-ND 4.0), which permits the noncommercial replication and distribution of the article with the strict proviso that no changes or edits are made and the original work is properly cited (including links to both the formal publication through the relevant DOI and the license). See: https://creativecommons.org/licenses/by-nc-nd/4.0/.

\section{References}

1. Nawrocki S, Cha J. The etiology, diagnosis, and management of hyperhidrosis: A comprehensive review: Etiology and clinical work-up. J Am Acad Dermatol 2019;81:657-66.

2. Schick CH. Pathophysiology of Hyperhidrosis. Thorac Surg Clin 2016;26:389-93.

3. McConaghy JR, Fosselman D. Hyperhidrosis: Management Options. Am Fam Physician 2018;97:729-34.

4. Nawrocki S, Cha J. The etiology, diagnosis, and management of hyperhidrosis: A comprehensive review: Therapeutic options. J Am Acad Dermatol 2019;81:669-80.

5. Purtuloglu T, Atim A, Deniz S, et al. Effect of radiofrequency ablation and comparison with surgical sympathectomy in palmar hyperhidrosis. Eur J Cardiothorac Surg 2013;43:e151-4.

6. Wolosker N, Leiderman DBD, de Campos JRM, et al. Number of Preoperative Hyperhidrosis Sites Does Not Affect the Sympathectomy Postoperative Results and Compensatory Hyperhidrosis Occurrence. Thorac Cardiovasc Surg 2019;67:407-14.

7. Akil A, Semik M, Fischer S. Efficacy of Miniuniportal Video-Assisted Thoracoscopic Selective Sympathectomy 
(Ramicotomy) for the Treatment of Severe Palmar and Axillar Hyperhidrosis. Thorac Cardiovasc Surg 2019;67:415-9.

8. Lembrança L, Wolosker N, de Campos JRM, et al. Videothoracoscopic Sympathectomy Results after Oxybutynin Chloride Treatment Failure. Ann Vasc Surg 2017;43:283-7.

9. Bryant AS, Cerfolio RJ. Satisfaction and compensatory hyperhidrosis rates 5 years and longer after video-assisted thoracoscopic sympathotomy for hyperhidrosis. J Thorac Cardiovasc Surg 2014;147:1160-3.e1.

10. Moon DH, Kang DY, Kim DW, et al. Early results of new endoscopic thoracic sympathectomy for craniofacial hyperhidrosis. J Thorac Dis 2018;10:3627-31.

11. Wang HY, Zhu YJ, Liu J, et al. The relationship between preoperative psychological evaluation and compensatory sweating. J Cardiothorac Surg 2018;13:42.

12. de Campos JR, da Fonseca HV, Wolosker N. Quality of Life Changes Following Surgery for Hyperhidrosis. Thorac Surg Clin 2016;26:435-43.

13. Weksler B. Is there light at the end of the tunnel for patients with severe compensatory hyperhidrosis? J Thorac Cardiovasc Surg 2017;154:e117.

14. Wolosker N, Milanez de Campos JR, Fukuda JM. Management of Compensatory Sweating After Sympathetic Surgery. Thorac Surg Clin 2016;26:445-51.

15. Qian K, Feng YG, Zhou JH, et al. Anxiety after Sympathectomy in patients with primary palmar hyperhidrosis may prolong the duration of compensatory hyperhidrosis. J Cardiothorac Surg 2018;13:54.

16. Du X, Zhu X, Wang T, et al. Compensatory hyperhidrosis after different surgeries at the same sympathetic levels: a meta-analysis. Ann Transl Med 2018;6:203.

17. Dobosz L, Cwalina N, Stefaniak T. Influence of Body Mass Index on Compensatory Sweating in Patients after Thoracic Sympathectomy due to Palmar Hyperhidrosis. Thorac Cardiovasc Surg 2017;65:497-502.

18. Jeong JY, Park HJ, Park JK, et al. Predictive procedure for compensatory hyperhidrosis before sympathectomy: preliminary findings. Thorac Cardiovasc Surg 2014;62:434-8.

19. Kara M, Kose S, Ozkan B, et al. Does clip removal help for compensatory hyperhidrosis complicating thoracic sympathetic clipping? Clin Auton Res 2019;29:353-5.

20. Hynes CF, Marshall MB. Reversibility of Sympathectomy for Primary Hyperhidrosis. Thorac Surg Clin 2016;26:421-6.

21. Sugimura H, Spratt EH, Compeau CG, et al. Thoracoscopic sympathetic clipping for hyperhidrosis: long-term results and reversibility. J Thorac Cardiovasc Surg 2009;137:1370-6; discussion 1376-7.
22. Horslen LC, Wilshire CL, Louie BE, et al. LongTerm Impact of Endoscopic Thoracic Sympathectomy for Primary Palmar Hyperhidrosis. Ann Thorac Surg 2018;106:1008-12.

23. Joo S, Lee GD, Haam S, et al. Comparisons of the clinical outcomes of thoracoscopic sympathetic surgery for palmar hyperhidrosis: $\mathrm{R} 4$ sympathicotomy versus $\mathrm{R} 4$ sympathetic clipping versus $\mathrm{R} 3$ sympathetic clipping. J Thorac Dis 2016;8:934-41.

24. Cai SW, Shen N, Li DX, et al. Compensatory sweating after restricting or lowering the level of sympathectomy: a systematic review and meta-analysis. Clinics (Sao Paulo) 2015;70:214-9.

25. Teivelis MP, Varella AY, Wolosker N. Expanded level of sympathectomy and incidence or severity of compensatory hyperhidrosis. J Thorac Cardiovasc Surg 2014;148:2443-4.

26. Gunn TM, Davis DM, Speicher JE, et al. Expanded level of sympathetic chain removal does not increase the incidence or severity of compensatory hyperhidrosis after endoscopic thoracic sympathectomy. J Thorac Cardiovasc Surg 2014;148:2673-6.

27. Aoki H, Sakai T, Murata H, et al. Extent of sympathectomy affects postoperative compensatory sweating and satisfaction in patients with palmar hyperhidrosis. J Anesth 2014;28:210-3.

28. Chen JP, Chen RF, Peng AJ, et al. Is compensatory hyperhidrosis after thoracic sympathicotomy in palmar hyperhidrosis patients related to the excitability of thoracic sympathetic ganglions? J Thorac Dis 2017;9:3069-75.

29. Deniz S, Kavakli K, Caylak H, et al. Treatment of compensatory hyperhidrosis of the trunk with radiofrequency ablation. Agri 2015;27:42-6.

30. Amr SA, Reyad RM, Othman AH, et al. Comparison between radiofrequency ablation and chemical neurolysis of thoracic splanchnic nerves for the management of abdominal cancer pain, randomized trial. Eur J Pain 2018;22:1782-90.

31. Leiderman DBD, Milanez de Campos JR, Kauffman P, et al. The relation between age and outcomes of thoracic sympathectomy for hyperhidrosis: The older the better. J Thorac Cardiovasc Surg 2018;156:1748-56.

32. Zhang $W$, Wei $Y$, Jiang $H$, et al. T3 versus T4 thoracoscopic sympathectomy for palmar hyperhidrosis: a meta-analysis and systematic review. J Surg Res 2017;218:124-31.

Cite this article as: Han JW, Kim JJ, Kim YH, Kim IS, Jeong SC. New sympathicotomy for prevention of severe compensatory hyperhidrosis in patients with primary hyperhidrosis. J Thorac Dis 2020;12(3):765-772. doi: 10.21037/ jtd.2019.12.91 